\title{
PENGGUNAAN NAMA DIRI MASYARAKAT BUGIS
}

\author{
Syamsul Rijal \\ Fakultas Keguruan dan Ilmu Pendidikan Universitas Pancasakti \\ Jalan A. Mangerangi 73, Makassar, Sulawesi Selatan \\ emal: rijal1703@yahoo.com.
}

\begin{abstract}
Use of Self Name in Bugis Society. This study describes the comparison between the proper name in the Bugis language with name nonlanguage Bugis and the factors that influence the naming of the Bugis community. Data collected through observation with note technique. The data collected were analyzed descriptively. The names of the Bugis have equivalents in other languages. There are seven factors that influence the selection process on behalf Bugis society, namely: (1) religion, (2) trends, (3) pride, (4) prestige, (5) heredity, (6) retention of identity, and (7) conditions or circumstances.
\end{abstract}

\begin{abstract}
Abstrak: Penggunaan Nama Diri pada Masyarakat Bugis. Penelitian ini mendeskripsikan perbandingan antara nama diri dalam bahasa Bugis dengan nama diri nonbahasa Bugis dan faktorfaktor yang memengaruhi pemberian nama dalam masyarakat Bugis. Data dikumpulkan melalui observasi dengan teknik catat. Data terkumpul dianalisis secara deskriptif. Nama-nama orang Bugis memiliki padanan dengan bahasa lain. Terdapat tujuh faktor yang memengaruhi proses pemilihan nama diri pada masyarakat Bugis, yakni: (1) agama, (2) tren, (3) kebanggaan, (4) gengsi, (5) keturunan, (6) pemertahanan identitas, dan (7) kondisi atau keadaan.
\end{abstract}

Kata kunci: nama diri, sikap bahasa, masyarakat Bugis

Bahasa merupakan salah satu unsur kebudayaan. Bahasa adalah faktor yang menyebabkan terjadinya kebudayaan. Bahasa terlibat dalam semua aspek kebudayaan, paling sedikit dengan cara memunyai nama atau istilah bagi unsur-unsur dari semua aspek kebudayan itu (Nababan, 1991:50). Di sinilah bahasa sangat berperan dalam menandai sebuah benda sebagai simbolnya.

Pemberian nama kepada seorang anak dalam konteks budaya adalah sesuatu yang sangat esensial sifatnya. Anggapan seperti itu juga berlaku dalam kehidupan masyarakat Bugis yang sangat menyakralkan arti sebuah nama. Dalam nama seorang anak, terdapat harapan dan doa yang dititipkan orang tua agar kelak setelah dewasa si anak akan mengikuti arti nama yang melekat pada dirinya.

Selain itu, penggunaan nama diri pada seseorang bukan hanya sekadar doa dan harapan, melainkan nama juga berfungsi sebagai penanda sosial seseorang dalam masyarakat. Kebanyakan orang yang disegani dalam kehidupan sosial masyarakat hanya karena sebuah nama yang telah dikenal dalam masyarakat. Di Sulawesi Selatan misalnya, nama-nama yang dibelakangnya melekat kata Kalla, Habibie, Yasin Limpo, Kahar Muzakkar, dan lain-lain. tentu akan mendapat respon yang berbeda dibandingkan dengan nama-nama seperti Rahim, Rahman, Ardi, Arman, dan lain-lain. Hal tersebut menunjukkan bahwa nama pun dapat memengaruhi keturunan dan kelas sosial seseorang dalam masyarakat.

Masyarakat Batak selalu memberikan nama kepada anak atau keturunannya sesuai dengan garis keturunan ayah dalam keluarga. Dengan demikian, nama-nama orang Batak dapat menjadi alat pemersatu jika suatu saat mereka keluar dari komunitasnya lalu bertemu dengan sesama marganya. Mereka pasti akan mengenali dan mengakui bahwa nama marga yang sama adalah berasal dari satu keturunan atau satu silsilah keluarga meskipun mereka belum saling mengenal sebelumnya. Hal ini sejalan dengan fungsi bahasa yang katakan oleh Fishman "contrastive self-identification"(identifikasi-diri yang kontrastif) atau yang oleh Garvin dan Mathiot 
disebut sebagai "unifying and separating function" (fungsi menyatukan dan sekaligus memisahkan) (Sumarsono, 2008:169). Jika seseorang keturunan Batak dari marga Situmorang bertemu dengan sesamanya tentu mereka akan mengidentifikasi dirinya sebagai satu keluarga, namun pada sisi lain, secara tidak sadar mereka telah memisahkan diri dari marga-marga lainnya.

Penggunaan nama juga dapat menunjukkan kebangsawanan seseorang, seperti gelar Andi pada masyarakat Bugis, dan La Ode atau Wa Ode pada masyarakat Buton. Selain itu, nama dapat pula menjadi penanda jumlah atau tingkat kelahiran dalam satu keluarga, seperti nama-nama pada masyarakat Bali. Semua penggunaan tanda untuk nama-nama dalam masyarakat $\mathrm{Bu}-$ gis, Buton, dan Bali adalah salah satu ciri sosial yang menunjukkan kesukuannya. Jika mereka berada dalam komunitas di luar komunitasnya, pasti sangat mudah dikenali meskipun mereka telah berbicara dengan bahasa yang digunakan oleh masyarakat setempat.

Masyarakat Bugis yang pada umumnya memeluk agama Islam lebih banyak memberikan nama-nama yang berbau bahasa Arab kepada anaknya. Nama yang berbahasa Arab diberikan kepada anak karena orang tua beranggapan bahwa bahasa Arab identif dengan bahasa Alquran yang merupakan kitab suci dan pedoman keselamatan orang Islam.

Nama anak yang baik adalah nama yang mengandung arti doa atau harapan baik untuk kehidupan akhirat kelak Thalib (2002: 9-10). Nama yang baik memunyai ciri-ciri: (1) mengandung makna pujian, misalnya: Ahmad atau Muhammad, yang berarti terpuji; (2) mengandung doa dan harapan, misalnya: Ali, yang berarti yang tinggi; Shalih, artinya yang baik; (3) mengandung makna semangat, misalnya: Saifullah artinya pedang Allah; Qamaruddin, artinya (cahaya) bulan agama.

Ciri-ciri nama yang diberikan oleh Thalib sedikit sejalan dengan pedoman pemberian nama-nama bugis dari orang tua kepada anaknya. Perbedaannya terletak pada perbedaan jenis kelamin dengan makna nama yang diberikan. Lakilaki biasanya diberikan nama yang mengandung makna keberanian sedangkan perempuan yang nama mengandung doa. Anggapan demikian melahirkan nama-nama bugis seperti untuk laki-laki biasanya prefiks mappa dikombinasikan dengan kata-kata lain misalnya: mappangara, mappa- renta, mappatoba, mapparessa, dan lain-lain. sedangkan untuk perempuan biasanya kata tenri dikombinasikan dengan kata-kata lain seperti: tenri pada, tenri gangka, tenri sangka, tenri awaru, tenri sompa, tenri cacca, dan lain-lain.

Fenomena kebahasaan seperti dalam penjelasan di atas telah banyak menginterferensi bahasa-bahasa daerah termasuk bahasa Bugis. Hal tersebut sangat menarik untuk diteliti lebih jauh dengan membandingkan nama-nama dari bahasa Bugis dengan bahasa-bahasa serapan lainnya yang memiliki arti yang mirip. Oleh karena itu, tulisan ini disusun untuk menyelidiki perbandingan nama-nama orang Bugis yang berba-hasa Bugis dengan nama-nama dari bahasa di luar bahasa Bugis.

Gambaran dalam latar belakang di atas merupakan salah satu fenomena kebahasaan yang hampir terjadi pada semua bahasa-bahasa daerah di Indonesia. Fenomena tersebut sedikit menginterferensi bahasa asli, termasuk bahasa Bugis yang sampai sekarang masih bertahan pemakainya dan pemakaiaannya. Salah satu bentuk interferensi tersebut adalah penggunaan namanama Bugis pada masyarakat Bugis yang sangat jarang lagi ditemukan saat ini.

Penelitian ini bertujuan mendeskripsikan nama-nama orang Bugis yang memiliki padanan dengan bahasa lain dan membandingkan makna dari dua nama bagaimana sikap bahasa penutur bahasa Bugis terhadap penggunaan nama dari bahasanya sendiri.

\section{METODE}

Data yang terdapat dalam tulisan ini merupakan kumpulan dari nama-nama orang Bugis yang diambil secara acak sesuai dengan tujuan penelitian. Nama-nama tersebut adalah nama yang dianggap masih menggunakan bahasa $\mathrm{Bu}-$ gis dan nama-nama yang tidak menggunakan bahasa Bugis.

Metode pengumpulan data dilakukan dengan observasi bebas. Cara ini dilakukan dengan teknik catat, yakni mencatat nama-nama yang ditemukan dalam berbagai ranah kehidupan masyarakat. Cara tersebut seperti: mencatat namanama teman sekolah, teman kuliah, tetangga, keluarga, teman dari teman, keluarga dari teman, teman sepermainan; daftar hadir mahasiswa penulis; daftar nama teman penulis dalam situs pertemanan facebook; dan beberapa nama yang per- 
nah ditemui dan dibaca oleh penulis. Populasi data tersebut kembali dipilih untuk dijadikan sampel penelitian dengan memilih nama-nama dari bahasa serapan yang memiliki padanan dalam bahasa Bugis dan sebaliknya, nama-nama Bugis yang memiliki padanan dalam bahasa serapan yang lain.

Beberapa data yang telah ditemukan dianalisis dengan menggunakan beberapa teori dalam sosiolinguistik. Data tersebut dianalisis dengan membandingkan sikap-sikap bahasa orang Bugis dalam memilihkan nama-nama diri untuk anaknya (analisis komparatif). Analisis inilah yang akan dideskripsikan untuk menemukan faktor-faktor yang memengaruhi pemilihan nama dalam masyarakat Bugis.

\section{HASIL}

\section{Nama-nama Orang Bugis yang Memiliki Pa- danan dengan Bahasa Lain}

Sesuai dengan data yang telah dikumpulkan, berikut ditampilkan nama orang Bugis yang memiliki padanan dalam bahasa lain. (1) Rezki memiliki arti yang serupa dengan Dalle, (2) Ayu memiliki arti yang serupa dengan Cenning, (3) Muhammad memiliki arti yang serupa dengan Mapparenta, (4) Faishal/hakim memiliki arti serupa dengan Mapparessa, (5) Adam memiliki arti yang serupa dengan Mappatoba, (6) Hadi memiliki arti yang serupa dengan Parenrengi, (7) Putri Ayu memiliki arti yang serupa dengan Indo Cenning, dan (8) Adiputra memiliki arti yang serupa dengan Ambo Masse.

Kedelapan data yang telah ditampilkan di atas, selanjutnya dianalisis berdasarkan sikap bahasa penuturnya yang diuraikan sebagai berikut. Rezki memiliki arti yang serupa dengan Dalle. Kata rezki yang diserap dari bahasa Arab merupakan salah satu nama yang sangat banyak digunakan oleh masyarakat Bugis. Kata rezki ini sebenarnya memiliki padanan kata yang serupa dalam bahasa Bugis, yaitu kata dalle. Dahulu kita masih dapat menjumpai nama dalle ini, yang biasanya kalau dalam sapaan Bugis menjadi $L a$ Dalle (untuk laki-laki) atau I Dalle (untuk perempuan). Akan tetapi, pada saat sekarang, kita sudah susah menjumpai nama-nama seperti itu, kalau memang masih ada, pasti usia orang itu sudah tua.
Seiring perkembangan zaman, penggunaan nama dalle ini semakin tergeser dengan bahasa-bahasa lain yang hidup berdampingan dengan bahasa Bugis termasuk bahasa Indonesia. Sekarang nama dalle ini hampir sepe-nuhnya tergantikan dengan nama rezki. Hal ini disebabkan oleh adanya faktor gengsi orang tua memberikan nama untuk anaknya dengan kata dalle karena dianggap terlalu kuno atau tidak lagi sesuai dengan zaman sekarang.

Padahal jika dilihat dari segi arti, kedua nama itu sama. Bahkan, jika orang Bugis yang memiliki nama rezki ditanya tentang makna namanya, mereka akan menjawab dengan kata dalle. Tentu kata dalle ini lebih dipahami maknanya dibanding dengan kata rezki yang memang bukan kosakata asli bahasa Bugis.

Аyи memiliki arti yang serupa dengan Cenning. Kata ayu dalam bahasa Jawa berarti 'cantik', 'anggun', 'menawan'. Jika dikonversi ke dalam bahasa Bugis maknanya kira-kira sama dengan cenning. Orang tua Bugis dahulu masih ada menggunakan nama I Cenning. Namun, sekarang nama seperti itu susah lagi dijumpai karena telah tergeser dengan kata ayu. Kata ayu ini lebih disenangi oleh sebagian orang Bugis karena kendengaran lebih keren dan modern dibanding dengan kata cenning. Dengan demikian, dapat dikatakan bahwa orang-orang Bugis merasa gengsi menggunakan kosakata bahasanya sendiri. Padahal makna kata cenning pasti lebih dipahami dibanding dengan kata $а у и$ yang berasal dari kosakata bahasa Jawa.

Muhammad memiliki arti yang serupa dengan mapparenta. Hampir seratus persen orang Bugis memeluk agama Islam. Agama Is-lam ini merupakan agama yang sudah menjadi agama turun-temurun dalam masyarakat Bugis. Pusatpusat pendidikan agama Islam didirikan di berbagai wilayah yang bersuku Bugis. Agama Islam akhirnya semakin mengakar dalam masyarakat Bugis sebagai agama yang dipercaya dapat memberi keselamatan dunia dan akhirat.

Agama Islam mengajarkan berbagai jalan keselamatan dan kebahagian. Salah satunya dengan jalan memilih nama yang baik dan tentu sesuai dengan kitab tuntunan orang Islam, yakni Alquran. Dalam masyarakat, ada anggapan bahwa bahasa Arab identif dengan bahasa Alquran karena di dalam melaksanakan ibadah khususnya salat, umat Islam membaca Alquran yang menggunakan bahasa Arab. 
Selanjutnya, berkembanglah ajaran-ajaran untuk memberikan nama-nama kepada anak dengan menggunakan bahasa Arab atau dengan memilih penggalan-penggalan ayat dalam Alquran. Salah satu kata atau nama yang paling banyak muncul dalam Alquran adalah Muhammad. Muhammad ini adalah nama nabi terakhir dalam tarikh Islam dan diakui sebagai nabi yang dapat mempersatukan dan memimpin ummat dengan baik. Jadi, arti kata muhammad kira-kira serupa dengan kata mapparenta dalam bahasa Bugis. Mapparenta dapat berarti 'orang yang memerintah atau pemimpin'. Nama muhammad inilah yang sering dikombinasikan dengan kata lain untuk dijadikan sebagai sebuah nama.

Nama-nama orang yang menggunakan kata muhammad sekarang sudah sangat banyak tetapi sangat susah lagi ditemukan nama mapparenta karena orang Bugis lebih meyakini kata muhammad sebagai nama yang bisa memberikan efek kebaikan bagi anaknya. Meskipun demikian, nuansa makna kedua kata tersebut tentu masih dapat dirasakan perbedaannya oleh orang Bugis sebagai penutur asli. Kata mapparenta tidak dapat sepenuhnya diwakili oleh kata muhammad, begitu pula sebaliknya, kata muhammad tidak dapat diwakili secara tepat maknanya oleh kata mapparenta.

Faishal/hakim memiliki arti serupa dengan Mapparessa. Kata faishal dan hakim adalah dua kata dalam bahasa Arab yang memiliki arti yang sama, yakni 'penengah' atau 'seorang yang bijak dan adil dalam menyelesaikan segala urusan' (Thalib, 2002: 129). Dalam bahasa Bugis, ada kata mapparessa yang artinya 'memeriksa'. Kata faishal/hakim ini memiliki arti yang serupa dengan mapparessa dalam bahasa Bugis yang sering digunakan sebagai sebuah nama.

Seiring perkembangan, kata faishal atau hakim ini lebih banyak juga digunakan sebagai nama oleh orang bugis karena orang Bugis merasa kata itu berasal dari bahasa Arab dan dianggap islami dibandingkan kata mapparessa dalam bahasa Bugis. Meskipun demikian, kata mapparessa ini lebih dipahami maknanya oleh orang Bugis sebagai penutur asli. Inilah salah satu bentuk pemilihan nama yang dipengaruhi oleh faktor agama khususnya agama Islam.

Adam memiliki arti yang serupa dengan Mappatoba. Kata Adam adalah nama nabi pertama dalam tarikh Islam yang dibuang ke dunia karena melanggar perintah Allah. Setelah peristiwa itu, Adam segera bertaubat kepada Allah dan menyesali kesalahannya. Berdasarkan hal tersebut, nama adam ini dianggap memiliki sifat yang segera bertaubat dari kesalahan (Thalib, 2002: 36). Jika nama adam ini diberikan orang tua kepada anaknya sesuai dengan makna taubat berarti kata tersebut memiliki padanan kata yang memiliki makna serupa dalam bahasa Bugis, yaitu kata mappatoba yang artinya orang yang bertaubat.

Penggunaan nama adam sekarang lebih banyak digunakan dibanding dengan kata mappatoba. Orang tua cenderung memilih kata adam karena dalam agama Islam nama adam ini dikenal sebagai nabi pertama. Namun, nama mappatoba ini masih dapat ditemukan sekarang ini tetapi terbatas pada kelas sosial tertentu. Biasanya hanya keturunan-keturunan bangsawan yang menggunakannya seperti Andi Mappatoba. Jadi, faktor keturunan juga dapat memengaruhi sikap bahasa dalam pemilihan nama orang-orang Bugis.

Hadi memiliki arti yang serupa dengan Parenrengi. Kata parenrengi yang berasal dari kata dasar renreng yang berarti 'tuntun'. Jadi, parenrengi berarti 'orang yang menuntun kita berjalan'. Kata parenrengi ini memiliki makna yang serupa dengan kata hadi dalam bahasa Arab yang berarti 'penunjuk (jalan)' (Thalib, 2002: 32).

Orang-orang Bugis lebih senang menggunakan nama hadi yang dianggap memiliki makna yang bagus karena berasal dari bahasa Arab yang identif dengan Alquran. Kata parenrengi ini biasanya hanya digunakan oleh orang Bugis yang berdarah bangsawan sehingga sering kita dengar nama Andi Parenrengi.

Putri Ayu memiliki arti yang serupa dengan Indo Cenning. Seperti yang telah dipaparkan pada data kedua penelitian ini bahwa kata ayu memilki arti yang serupa dengan kata cenning dalam bahasa Bugis. Jadi, kata putri dari bahasa Sansekerta kira-kira memiliki arti yang serupa dengan kata indo dalam bahasa Bugis. Dengan demikian, paduan kata putri ayu dalam bahasa Jawa dan Sansekerta kira-kira memiliki makna yang sepadan dengan paduan kata indo cenning dalam bahasa Bugis.

Salah satu pertanyaan besar sekarang, masih adakah orang tua yang mau memberikan nama kepada anaknya seperti nama indo cenning. Lebih banyak yang memilih nama putri ayu karena orang-orang Bugis selalu menjaga gengsi dan ikut tren dalam masyarakat. Jika dibanding- 
kan nuansa maknanya, pasti orang Bugis lebih memahami makna nama indo cenning daripada putri ayu karena nama indo cenning berasal dari bahasanya sendiri.

Adiputra memiliki arti yang serupa dengan Ambo Masse. Kata adiputra berasal dari dua kata, yaitu adi yang berarti kuat dan putra berarti 'anak laki-laki'. Paduan kata adiputra ini kira-kira memiliki makna yang serupa dengan ambo masse dalam bahasa Bugis. Kata ambo dapat mewakili arti putra dan kata masse dapat mewakili kata adi. Namun, sekarang kita susah lagi menemukan paduan kata seperti ambo masse ini. Orang-orang Bugis lebih senang memilih kata adiputra karena dianggap lebih modern dan tidak ketinggalan zaman.

Paduan kata ambo ini masih dapat ditemukan di beberapa daerah yang berpenduduk orang Bugis seperti di Kabupaten Wajo dan sebagian wilayah Sidrap. Sebagian besar dapat ditemukan pada komunitas penganut kepercayaan To Lotang di Kabupaten Sidrap.

\section{Faktor-faktor yang Memengaruhi Pemberian Nama dalam Masyarakat Bugis.}

\section{Faktor Agama}

Suatu hal yang tidak dapat dipungkiri sebagai salah satu penyebab sikap bahasa tersebut adalah adanya pengaruh kuat agama Islam dalam kebudayaan masyarakat Bugis. Bahasa Arab selalu dianggap sama dengan bahasa Alquran yang di dalamnya terdapat kebenaran mutlak menurut orang muslim. Dengan demikian, orang tua lebih banyak memilih nama-nama dari bahasa Arab karena dianggap dapat menjadi cerminan apa yang dilukiskan dalam Alquran tersebut. Nama seseorang kelak akan dipergunakan sampai akhirat dan orang tualah yang akan mempertanggungjawabkan baik-buruknya nama anak-anaknya (Thalib, 2002: 14).

\section{Tren dalam Masyarakat}

Media massa yang telah memasuki hampir setiap lini kehidupan masyarakat adalah satu penyebab masyarakat selalu ingin mengikuti halhal yang lagi menjadi tren. Televisi adalah salah satu media yang sangat cepat memengaruhi masyarakat. Televisi memberikan berbagai tontonan yang selalu bersifat baru. Tidak jarang yang mengadposi siaran-siaran pilihan dari luar negeri, misalnya film-film Korea, Jepang, India, Amerika, Inggris, bahkan film-film dari Malaysia pun juga sudah memasuki siaran-siaran nasional Indonesia.

Melalui tontonan siaran televisi ini, orang tua terasuki pikirannya dengan nama-nama tokoh dalam sebuah film atau nama-nama olahragawan, artis, tokoh bangsa, dan tokoh dunia yang sering mereka lihat. Karena terlalu sering menonton, mereka menjadi gemar dan ingin mengikuti atau menyamai tokoh tersebut. Akhirnya, kegemaran dan kecintaan terhadap sesosok tokoh itu kadang-kadang diabadikan lewat pemberian nama-nama diri kepada anaknya. Selanjutnya, bermunculanlah nama-nama seperti: Azizah, Ronal, Ibrahimovich, Saddam Husain, Kari$n a$, Bunga, dan lain-lain.

Jadi, yang dimaksud dengan tren di sini adalah fenomena aktual yang terjadi dalam masyarakat (Azhar, 2008: 14). Apalagi zaman sekarang ini, hampir semua peristiwa ditayangkan di televisi. Mulai hal-hal yang sangat penting sampai hal-hal tidak penting seperti berita perceraian artis. Semua itu pasti akan membekas dan memengaruhi penontonnya.

\section{Kebanggaan}

Penggunaan nama seseorang masih dianggap sebagai salah satu hal membanggakan jika nama tersebut sangat bagus artinya di mata masyarakat. Sama halnya dengan bahasa itu sendiri sebagai kosakata, nama juga memberikan kebanggaan tersendiri, baik bagi pemiliknya maupun orang yang memberikan nama itu (orang tua masing-masing). Orang-orang yang memiliki nama unik biasanya mudah diingat dan memberi kesan tersendiri, baik bagi pemiliknya maupun dalam masyarakat.

Jika dalam sebuah keluarga telah sukses dan dikenal masyarakat luas tentu simbol pertama yang paling dikenal adalah nama orang tersebut. Ketika keluarga tersebut menambahkan namanya di belakang nama asli anaknya tentu si anak juga ikut terkenal dan mendapat perhatian berbeda di dalam masyarakat.

Bagi sebagian orang Bugis, nama adalah sesuatu yang dapat memberikan wibawa tersendiri bagi pemiliknya. Anggapan itulah yang sebagian orang masih memberikan nama-nama kepada anaknya yang berbau atau berbahasa Bugis. Namun, hal tersebut masih terbatas dalam ma- 
syarakat karena penggunaan nama-nama yang berbahasa Bugis itu hanya digunakan oleh keluarga bangsawan atau keturunan Andi dalam kelas sosial masyarakat Bugis. Hal itulah yang menyebabkan sebagian orang masih memberikan nama-nama kepada anaknya terutama keluarga bangsawan seperti: Andi Balla Sada, Andi Patongai, Andi Mappatoba, Andi Panguriseng. Ada pula sebagian masyarakat Bugis yang masih menggunakan kata Ambo dan Indo kemudian dikombinasikan dengan kata-kata lain, seperti: Ambo Upe', Ambo Awe, Ambo Ranreng, Indo E$s a$, dan nama lainnya.

Selain nama-nama Bugis tersebut, ada pula nama-nama serapan dari bahasa lain yang juga dianggap dapat memberikan prestise atau wibawa tersendiri bagi pemiliknya. Nama-nama tersebut seperti: Arya, Cakra, Dimas, Duta, Ayu, Sri, Putri, Ika, Dirga, Budi, Dewi, dan lain-lain.

\section{Gengsi}

Pemberian nama kepada seorang anak biasanya masih dipertimbangkan secara historis oleh orang tua. Artinya, orang tua mempertimbangkan jenis bahasa yang akan digunakan sebagai nama anaknya. Bahasa-bahasa yang masih kental nuansa bugisnya biasanya dianggap sesuatu yang kuno karena tidak cocok lagi dengan zaman sekarang. Pertimbangan lain dari orang tua biasanya memikirkan kondisi psikologis si anak ketika bergaul dengan teman-temannya. Dalam pergaulan, anak-anak biasanya mengejek teman-temannya jika teman tersebut memiliki nama yang masih menggunakan bahasa-bahasa lama termasuk bahasa Bugis. Faktor inilah yang membuat orang tua tidak memberikan nama kepada anaknya yang menggunakan bahasa Bugis asli karena untuk menjaga gengsi anaknya kelak setelah dewasa.

\section{Keturunan}

Gelar kebangsawanan juga sangat memengaruhi pemberian nama seorang anak dalam masyarakat Bugis. Nama-nama kebangsawanan ini diwariskan secara turun-temurun berdasarkan garis keturunan ayah. Misalnya seseorang bernama Andi Paddaitu memberikan nama kepada anaknya dengan mengikutkan namanya sehingga nama anaknya menjadi Andi Latto Paddaitu. Setelah Andi Latto memiliki anak, nama Latto ini diikutkan lagi di belakang nama anaknya menjadi Andi Akibe Latto dan Andi Kubade Latto.

Pada sisi lain, orang-orang Bugis yang tidak termasuk dalam silsilah keluarga bangsawan kadang-kadang merasa malu menggunakan nama-nama bernuansa bangsawan. Nama mereka biasanya ditandai dengan prefiks atau kata sandang $L a$ dan $I$ dalam kelas sosial masyarakat. Kata sandang $L a$ dan $I$ inilah yang sering dikombinasikan dengan kata-kata lain seperti: La Upe, La Cilaleng, La Beddu, I Sennang, I Rejja, dan lain-lain.

\section{Pemertahanan Identitas}

Jika diperhatikan berdasarkan jumlah nama-nama orang Bugis yang menggunakan bahasa Bugis secara sengaja untuk mempertahankan identitas, faktor inilah yang paling sedikit. Sebenarnya faktor ini dapat bertumpang tindih dengan faktor lain seperti faktor prestise dan faktor keturunan. Namun, keluarga-keluarga bangsawan memberikan nama kepada anaknya kadangkadang tidak bermaksud untuk mempertahankan tradisi tetapi sekadar untuk menyambung silsilah keluarga dan menjaga wibawa. Jadi, sebenarnya mereka telah melanjutkan silsilah keluarga dan sekaligus secara tidak sengaja mempertahankan identitasnya sebagai orang Bugis.

Ada beberapa nama yang pernah ditemukan yang dipilih dengan sengaja untuk mempertahankan identitas seseorang sebagai orang Bugis. Misalnya seorang teman bernama I Sumarni. Berdasarkan kebiasaan, kita hanya sering menemukan nama Sumarni, tetapi orang tua I Sumar$n i$ menambahkan kata sandang $I$ di depan namanya dengan sengaja agar orang lain dapat mengenalnya sebagai orang Bugis. Hal ini dilakukan orang tua tersebut karena mereka sedang merantau di daerah lain dan bercampur dengan berbagai suku. Ada pula nama I Sabah yang lahir di salah satu wilayah negara Malaysia, yaitu Sabah. Supaya orang-orang mengenalnya sebagai orang Bugis, orang tuanya menambahkan kata sandang $I$ di depan namanya. Nama-nama lain yang pernah ditemukan adalah $L a$ Rusi, $L a$ Suridam, dan La Tasong.

Prefiks atau kata sandang $I$ dalam namanama orang Bugis sebenarnya tidak cukup untuk menandai sebagai seorang suku Bugis jika nama yang ada di belakangnya tidak berbahasa Bugis. Alasannya, sebagian orang Bali juga mengguna- 
kan kata sandang $I$ di depan namanya. Jadi, harus ada identitas tambahan untuk membedakan.

\section{Kondisi atau Keadaan}

Kadang-kadang pemberian nama diri bagi orang Bugis mengandung makna yang sangat filosofis. Makna-makna nama tersebut biasanya disesuaikan dengan kondisi atau keadaan yang melatarbelakangi proses kelahiran seorang anak. Misalnya, seorang yang bernama Andi Nissi Purnama, ternyata proses kelahirannya dilatarbelakangi oleh beberapa peristiwa. Pertama, Andi Nissi Purnama lahir tepat bulan purnama. Kedua, beberapa hari sebelum Andi Nissi Purnama lahir, orang tuanya sempat membeli mobil yang bermerek Nissan.

\section{PENUTUP}

Berdasarkan analisis komparatif sikap bahasa penutur bahasa Bugis terhadap penggu-

\section{DAFTAR PUSTAKA}

Alquran dan Terjemahannya. 1971. Kompleks Percetakan Al Karim Kepunyaan Raja Fahd.

Azhar, Iqbal Nurul. 2008. "Ketika Bahasa Madura Tidak Lagi Bersahabat dengan Kertas dan Tinta: Kajian Ethnolinguistik dari Sudut Pandang Sosiolinguistik", dalam Anwar Efendi, Bahasa dan Sastra: Dalam Berbagai Perspektif. Yogyakarta: Tiara Wacana.

Departemen Pendidikan Nasional. 2003. Kamus Besar Bahasa Indonesia: Edisi Ketiga. Jakarta: Balai Pustaka.

Mahsun. 2005. Metode Penelitian Bahasa. Jakarta: Rajawali Press. naan nama diri: (1) ditemukan sejumlah nama diri masyarakat Bugis yang memiliki padanan dengan bahasa lainnya; (2) faktor yang memengaruhi proses pemilihan nama-nama diri pada masyarakat Bugis, yakni: (a) agama, (b) tren, (c) prestise, (d) gengsi, (e) keturunan, (f) pemertahanan identitas, dan $(\mathrm{g})$ kondisi atau keadaan. Ketujuh faktor inilah yang memengaruhi orang Bugis dalam memilih nama untuk anaknya, baik nama-nama diri yang berasal dari kosakata bahasa lain, maupun bahasa yang berasa dari bahasa Bugis itu sendiri.

Selain itu, ada hal menarik pada masyarakat Bugis terkait dengan sikap bahasa dalam memilih nama diri dengan pemertahanan bahasa Bugis sampai saat ini. Penutur bahasa Bugis tetap menggunakan bahasanya dalam pergaulan sehari-hari tetapi mereka memiliki pandangan kurang baik (sikap negatif) terhadap bahasanya dalam hal memilih nama diri. Justru mereka memandang positif penggunaan kosakata bahasa lain untuk dijadikannya sebagai nama diri.

Nababan, P.W.J. 1991. Sosiolinguistik: Suatu Pengantar. Jakarta: Gramedia Pustaka Utama.

Sapir, Edward. 1929. "The Status of Linguistic as a Sciences", in Edward Sapir, 1958, Culture, Language and Personality. Barkelay C.A.: University of California Press.

Sumarsono. 2008. Sosiolinguistik. Yogyakarta: Pustaka Pelajar.

Taha, Zainuddin. 2008. Gapura Bahasa: Kumpulan Makalah Pilihan tentang Bahasa dan Pengajaran Bahasa. Makassar: Badan Penerbit UNM.

Thalib, Muhammad. 2002. Tuntunan Islami Memberi Nama Anak. Bandung: Irsyad Baitus Salam. 